\title{
Bigfoot hunting Academic library outreach to elementary school students
}

$\mathbf{T}$ he morning of May 25, 2012, the librarians at Columbus State Community College's Delaware Campus Learning Center awaited with nervous excitement the arrival of more than 70 fourth-graders from Laura Woodward Elementary School. Woodward Elementary School is located in Delaware, Ohio, and is part of the Delaware City School District. A few months earlier the dean and the assistant director of the Delaware Campus offered our library the opportunity to participate in a campus-wide program to introduce students to a day of college.

In our meetings with the Woodward Elementary principal and the fourth-grade teachers, we learned that history's mysteries and tragedies, such as the sinking of the Titanic, grabbed the students' attention. The teachers themselves expressed interest in career research and college resources, but we decided that our career assessment resources would be too advanced for the students and that too much time would be involved in students filling out career surveys. In the end, we decided to focus on information literacy and the evaluation of sources in our library session with the Woodward Elementary students because as academic librarians, we instruct college students on scholarly research to help them gain information literacy skills as outlined in ACRL's Information Literacy Competency Standards for Higher Education on a daily basis. ${ }^{1}$

We knew that we needed a fascinating topic to engage the students, and one of our librarians with a son in elementary school suggested Bigfoot. Who better than a mysterious, hairy ape-man to grab students' attention and help the fourth-graders explore how students at any level should conduct academic research?

Once we settled on Bigfoot as our topic, we narrowed our focus even further to how students should use the CRAP (Currency, Reliability/Relevance, Authority, and Purpose/ Point of View) test ${ }^{2}$ to evaluate Bigfoot. CRAP is an easy acronym for students to remember, and it identifies specific criteria for students to apply when evaluating sources. By giving the students two-to-four specific questions to ask for each criterion, they have a concrete mechanism for determining the worthiness of sources

For example, the questions for Currency could be, "When was the information last published or updated?" and "Is the information still current?" As a result, there is no guess work with such a checklist of questions, which leads to comprehensive review of any source. Evaluation remains an essential information literacy skill, especially in light of the intimidating amount of information available on any and every given topic; the CRAP test compels students to examine sources with a critical eye. In our introduction of the CRAP test to the elementary school students, we likened the hunt for Bigfoot to the hunt for appropriate sources and connected Bigfoot's strong odor to students using the CRAP test to identify "stinky" sources they should avoid.

Dana Knott is library coordinator, e-mail:dknott@cscc. edu, and Kristine Szabo is reference and instruction librarian, e-mail: kszabo@cscc.edu, at Columbus State Community College's Delaware Campus Learning Center

(c) 2013 Dana Knott and Kristine Szabo 
To reinforce the Bigfoot hunting theme, we employed a number of tactics and resources. First, we created a Bigfoot Field Guide folder for the students, as good investigators, to record their findings and evaluate their sources with criteria from the CRAP test. Next, we created a PowerPoint presentation with Bigfoot pictures galore, identified terminology, such as "cryptozoology," and highlighted criteria for evaluating sources. With TurningPoint, an audience response system integrated in PowerPoint, we included polls on whether the students believed in Bigfoot, and if they found specific sources credible after their evaluation. Third, we created a Wordle (word cloud) with different names for Bigfoot to reinforce the importance of using different search terms. Finally, we created a LibGuide just for this event with a lot of fun and interesting images, links, and sources. ${ }^{3}$

\section{Objectives}

While hunting for Bigfoot with the Woodward Elementary School students, we wanted to achieve the following objectives:

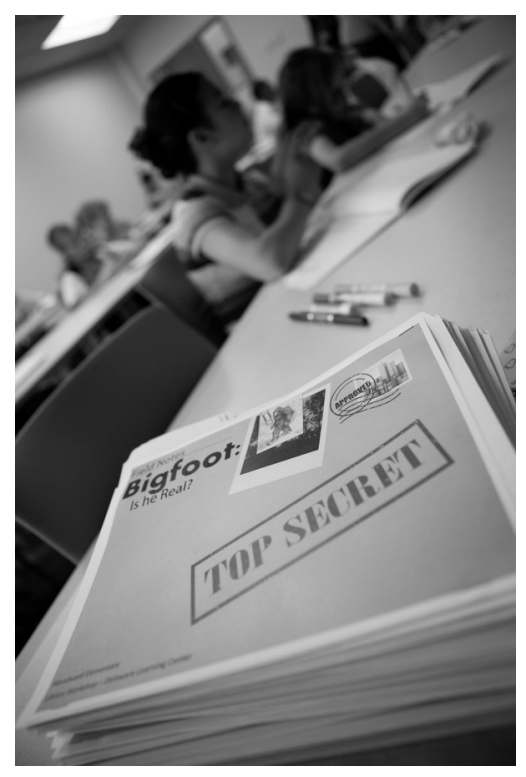

Bigfoot Field Guides (Photo: Mark Van Horn).
1. Students will learn that research requires critical thinking and time. Good researchers take the time to evaluate sources to separate the wheat from the chaff.

2. Students will appreciate the variety of sources they can use to conduct college research.

3. Students will learn different avenues of research they can follow.

4. As academic librarians our role as educators can reach beyond the college campus. We will create meaningful partnerships with other departments at the college and with other educational institutions to reinforce students' information literacy skills, skills students will require at each step of the educational process.
5. Most importantly, we want to engage the students, to make sure that they enjoy taking on the role of college researchers and that they have fun.

\section{Bigfoot hunting and information literacy}

The students' day of college began with a tour of the Delaware Campus guided by librarians, advisors, and administrators. On the Delaware Campus, services are centrally located in one building, so students were able to see how different areas, such as student services and library services, work together. After the tour, the students were divided into three manageable groups to experience three different courses: a science class in the lab where the students made "flubber" and Styrofoam "ice cream," a teleconferencing class where students experienced distance learning and talked to employees located at the Columbus Campus, and our library class on information literacy and Bigfoot.

When we introduced ourselves, we asked students to tell us what they thought librarians do. Most of the students believed that librarians mainly recommended or checked out books, so we explained our role as instruction and reference librarians. Happily, by the end of the day their perception had completely changed. Librarians now were considered smart professionals who helped people get "good" information and navigate the Internet and databases.

Throughout the classes, we made sure to use appropriate grade-level language and to be open, engaging, and humorous. We wanted to not only teach the students about doing college research, but to draw them in 
and engage them. It turns out that Bigfoot and cryptozoology was the perfect hook. By the end of each session the students were smiling, making intelligent comments, and clearly very engaged in the activities. We even had students with family members who claimed to have seen Bigfoot.

We asked students to picture themselves as investigators looking into the existence of Bigfoot, and just as an investigator examines clues, students should also examine the quality of their sources. We then gave students their investigative supplies; students loved the mood pencils and Bigfoot Field Guide folders, and the clickers fascinated them almost to the point of distraction.

During the class, we asked the students to evaluate a variety of sources. The first source was a video clip with eyewitness accounts from the television show Finding Bigfoot. The Bigfoot Field Researchers Organization Web site served as the second source, and a library book served as the third source. Students had to apply the CRAP test to each source and take notes in their Bigfoot Field Guide. We asked them to vote on each source and tell us whether it was a "good" source. In their reaction to the video, the students trusted the eyewitness accounts given by adults over those given by children. Interestingly, it turned out the more sources they evaluated the stricter they became. By the time students evaluated their library books, they really put the sources under the microscope. In fact, there were some sources that the librarians thought were good that the students did not. We made sure to mention other places students could find information, such as research databases, e-books, and our Bigfoot LibGuide, and that they could also access information from mobile devices.

It should be noted that the clickers worked perfectly the first time-and the first time only. Attempts to troubleshoot between sessions failed. In the two subsequent classes we took a vote by raised hands.

\section{Conclusion and lessons learned}

We were struck by our interactions with the students and their excitement from being on a real college campus. Many of the students had never visited a college, or even thought about attending one. Once they visited campus, college was really on their radar, and it was clear that some made attending college a goal. At the end of the students' day at Columbus State Community College, the dean presented each of them with a "graduation" certificate and college "swag." Students even got to meet Columbus State's mascot, Clawdette Cougar.

On the technical side, we learned that with any technology it's good to have a back-up plan. When the IT department could not fix the clicker problem we rolled with it and voted by a show of hands. However, not every fix is that easy, and we learned that we should prepare for technical failure-hope for the best and expect the worst-so that if it happens we will not be thrown for a loop.

This outreach opportunity really emphasized to us that our role as educators extends to people of all ages. The Woodward Elementary School visit also made us appreciate that partnerships between different academic institutions, such as Columbus State Community College and Laura Woodward Elementary School, and the collaboration that takes place among different college departments, can make wonderful things happen.

We look forward to future collaborations and embracing the "it takes a village" approach to educating students and helping them obtain the skills they need to lead successful lives.

\section{Notes}

1. "Information Literacy Competency Standards for Higher Education," www.ala.org/acrl /standards/informationliteracycompetency.

2. "The CRAP Test," LOEX 2008 Wiki-ing Your Way into Collaborative Learning Wiki, accessed June 6, 2013, http://loex2008collaborate. pbworks.com/w/page/ 18686701 /The\%20CRAP\%20Test.

3. The Bigfoot Hunting LibGuide is available at http://libguides.cscc.edu/bigfoot. $\boldsymbol{n}$ 